\title{
The nutritional status of children of pre-school age in the Guatemalan community of Amatitlán
}

\author{
2.* Comparison of dietary, clinical and biochemical findings $\dagger$
}

By M. BÉHAR, G. ARROYAVE, MARINA FLORES AND N. S. SCRIMSHAW

Institute of Nutrition of Central America and Panama (INCAP), Guatemala, C.A.

\section{(Received 17 Fuly 1959-Revised 22 December 1959)}

It has become increasingly clear that in most technically underdeveloped areas, especially in tropical regions, the major nutritional problem arises from inadequate feeding of the pre-school child. In Central America the mortality of children from the age of $I$ to 4 years is extremely high for this reason (Scrimshaw, Béhar, Pérez 8 Viteri, I955). In Guatemala the age-specific mortality rate at $I-4$ years was $42 \cdot \mathrm{I} \%$ in 1955 (Béhar, Ascoli \& Scrimshaw, I958). In four selected communities $35 \%$ of the children whose deaths were investigated showed signs of kwashiorkor (Béhar et al. 1958). The majority of the remainder died from acute infections which would not ordinarily be fatal to a well-nourished child. Previous nutritional studies of this age group in Central America have been limited to incomplete surveys in the lowerincome populations in Guatemala City (Carrascosa, 1956) and San Salvador (Instituto de Nutrición de Centro América y Panamá, unpublished). Furthermore, such investigations in comparable areas of the tropics and subtropics are rare, despite the magnitude and importance of the problem of malnutrition in the pre-school group.

The present paper describes the clinical, biochemical and dietary findings in a group of children under 7 years of age, living in a small semi-rural community. A comparison of the food intakes of the children under 5 by age group with the average diets of their families is given by Flores \& Garcia (1960).

\section{METHODS}

Community and population. Flores \& Garcia (1960) have described in detail the method of selecting the children and the characteristics of Amatitlan, the community selected. In June I955, forty children under 5 years of age in forty different families were examined for clinical and biochemical evidence of nutritional status, and dietary histories were obtained. In May 1956, clinical and biochemical data only were obtained for an additional sample containing thirty-seven other children under 7 . All came from families with monthly incomes of less than Q. 10.00 (quetzales and U.S. dollars are at par) per person. It was not possible to make all measurements on all seventy-seven children because of occasional difficulties with exceedingly unco-operative children and their withdrawal from the examination by the mothers.

- Paper no. 1 : Brit. F. Nutr. (1960), 14, 207.

+ INCAP Publication I-I37. 
Some mothers were willing to co-operate in most but not all aspects of the study. Furthermore, there were occasional losses of samples during the laboratory work.

Dietary study. The techniques used in obtaining the dietary histories have been described by Flores \& García (I960).

Clinical examination. A complete physical examination was carried out on each child, with special emphasis on those signs and symptoms described by Muñoz \& Pérez-Avendaño (1954). Skinfold thickness was measured according to the recommendation of Brožek \& Keys (I95I).

Haemoglobin was determined in both the 1955 and $195^{6}$ groups by the acidhaematin method with a Klett colorimeter. Red blood cell counts and haematocrits were determined in the former group by the methods of Wintrobe (1951). Stool specimens were examined for parasites.

Biochemical determinations. In 1955 , forty blood samples were collected for determination in the serum of: total proteins, alkaline phosphatase, amylase, carotene, vitamin A and ascorbic acid. In 1956, samples were obtained from thirty-seven additional children, and their serum was analysed for total proteins, cholinesterase, carotene, vitamin $A$, riboflavin and ascorbic acid.

One $\mathrm{ml}$ of blood was collected by finger-tip puncture and refrigerated. The serum was separated within $4 \mathrm{~h}$ of the time of collection and total serum proteins were determined immediately by the density-gradient method of Lowry \& Hunter (1945). A portion was used to prepare a trichloroacetic-acid filtrate for determination of ascorbic acid, as described by Lowry, López \& Bessey (1945). The rest of the serum was frozen at $-20^{\circ}$ until required. The following analyses were made: vitamin $A$ and carotene by the methods of Bessey, Lowry, Brock \& López (1946), riboflavin by the fluorimetric methods of Burch, Bessey \& Lowry (1948), alkaline-phosphatase activity by the technique of Bessey, Lowry \& Brock (1946), amylase and cholinesterase activities by the methods of Smith \& Roe (1949) and Reinhold, Tourigny \& Yonan (I953), respectively.

\section{RESULTS}

Dietary study

Values for eight children were not included in the results presented in Table 1 because they were breast-fed, either exclusively or with some supplementary foods.

Table I shows the considerable variations among thirty-two children which bore little consistent relationship to age. Eighteen received daily less than $5 \mathrm{~g}$ protein of animal origin, and of these, eight received none at all. Low intakes of vitamin A, riboflavin, ascorbic acid and fat were also common.

The inadequacy of these diets is shown more clearly if the intakes presented in Table I are compared with the recommended dietary allowances (Instituto de Nutrición de Centro América y Panamá, 1955). Of the thirty-two children, seven failed to meet one-half of the recommended allowance for calories, eleven for total protein, twenty-one for calcium, four for iron, twenty-five for vitamin A, six for thiamine, twenty-two for riboflavin, eleven for nicotinic acid, and nineteen for ascorbic acid. Thirteen children had less than $10 \%$ of the recommended allowance 


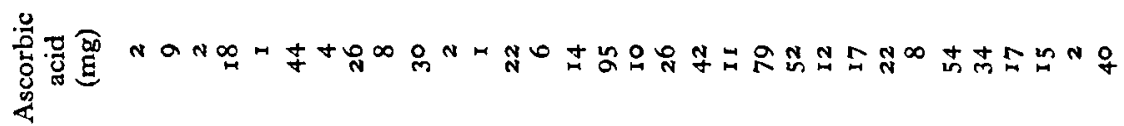

岁

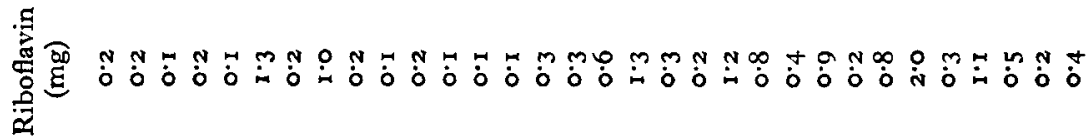

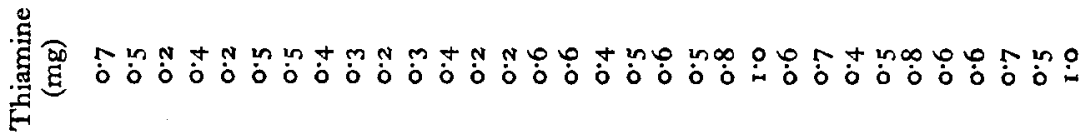

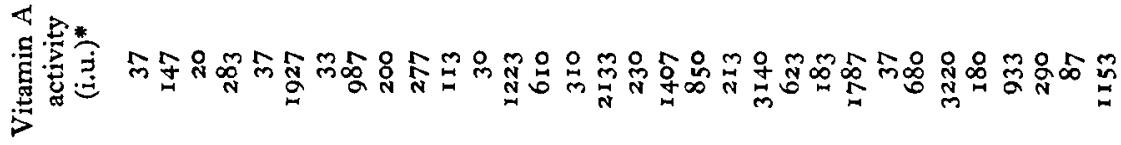

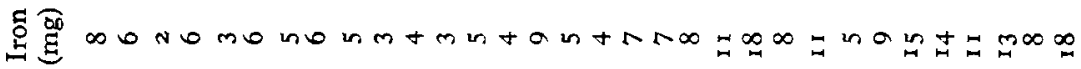

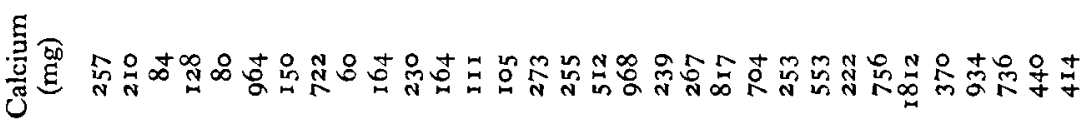

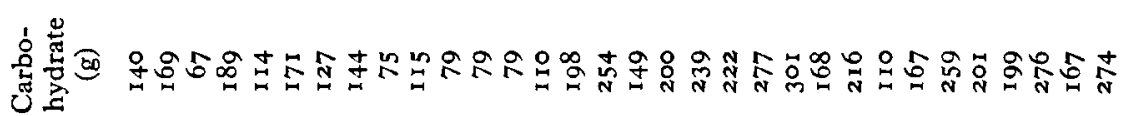

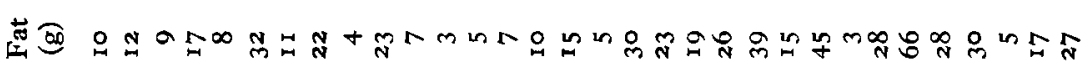
$\frac{\sqrt{3}}{3}$

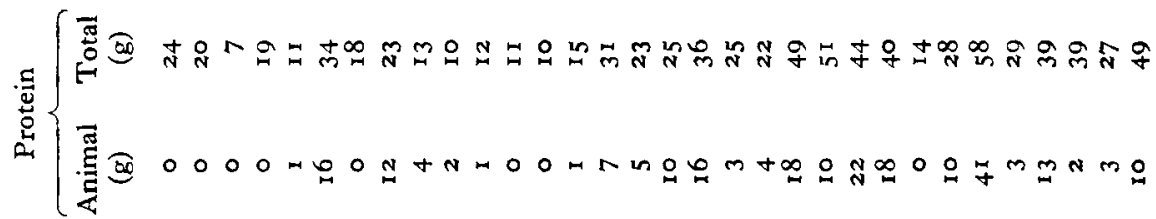

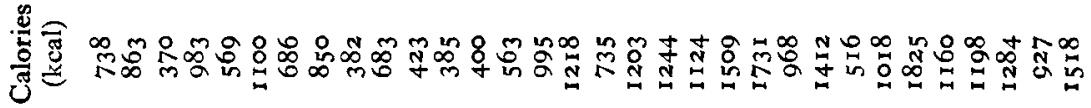
iI 离 苞 $\frac{0 c}{3}$ $\dot{0}$ $\frac{\ddot{\theta}}{\dot{m}}$ $\stackrel{8}{g}$

$\stackrel{8}{8}$

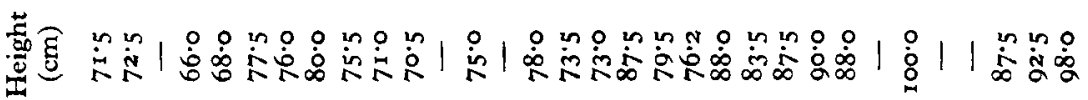

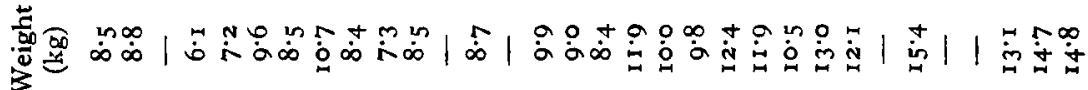
$\frac{\dot{0}}{\frac{0}{0}}$

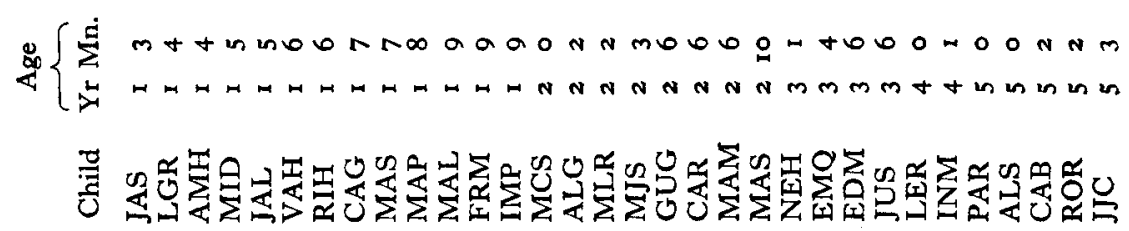


for vitamin A, six less than $10 \%$ of that for ascorbic acid and one less than $10 \%$ of that for thiamine. It should also be noted that in calculating the percentage of the recommended allowance met by the protein intake no account was taken of the fact that most of the protein was of vegetable origin and of relatively poor quality. This procedure would tend to underestimate the seriousness of the deficiency.

\section{Clinical findings}

In Fig. $x$ the individual heights and weights of the children are plotted against the curves of reference adopted by INCAP for well-nourished children (Instituto de Nutrición de Centro América y Panamá, 1952). These standards have been found suitable for well-nourished children in middle- and upper-income groups in Guatemala. Though they have considerably less admixture of Mayan Indian racial stock than the children in the survey, values for them are the only source of data now available for comparison.
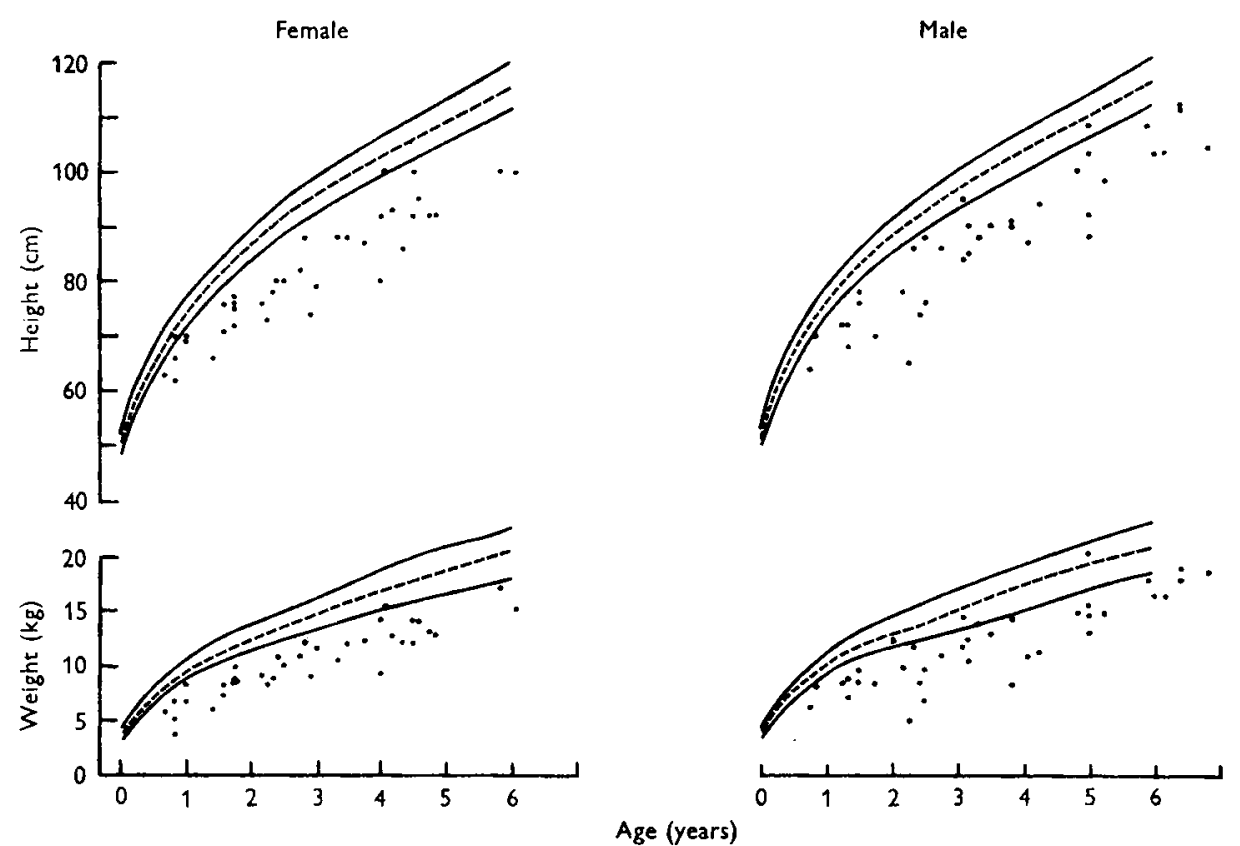

Fig. 1. Heights and weights of pré-school children in Amatitlán compared with INCAP standards. The dots represent individual measurements in our study, and the lines the standards. The broken lines represent the mean for height and the median for weight. The solid lines represent plus or minus one standard deviation for height and the 16 th and 84 th percentiles for weight.

Unpublished INCAP data show a similar degree of retardation in growth and maturation among Costa Rican children in low-income groups who by history, physical appearance and major blood-group distribution are essentially of European origin.

Nearly all the children fell below the sixteenth percentile in weight and more than one standard deviation below the mean in height. The height: weight ratio was much 
more nearly normal since there was a proportional reduction in both. It is also noteworthy that the degree of retardation was already marked at $\mathrm{I}$ year and continued throughout the age period included in the sample. The relative lack of subcutaneous fat in these children is revealed by the skinfold measures given in Table 2, which are very low compared with the values for children of similar age obtained in the recent nation-wide survey in Canada (Pett \& Ogilvie, 1957).

The frequency of clinical signs of possible interest in relation to nutritional status occurring in the population studied is listed in Table 3. The hair could be pulled out readily in eleven of seventy-five subjects examined and changes in texture and pigmentation were usually associated. Eight of these eleven were children $1-3$ years of age, and there was one in each of the age groups $\mathrm{O}_{-1}, 3^{-4}$, and $4^{-5}$ years. Although no cases of definitely abnormal dryness were noted, thickening and increased vascularization of the bulbar conjunctiva were common. The results for some children had to be omitted from the tabulation of eye signs because of lachrymation and vascularization as a result of crying. Vascular invasion of the corneal border of the type attributed to riboflavin deficiency was doubtfully observed in one child, and nasolabial seborrhoea in only two children.

Table 2. Mean values for skinfold thickness $(\mathrm{mm})$ in pre-school children in Amatitlán, 1955-6

\begin{tabular}{|c|c|c|c|c|c|c|c|c|}
\hline \multirow[b]{2}{*}{$\begin{array}{l}\text { Age group } \\
\text { (years) }\end{array}$} & \multicolumn{4}{|c|}{ Boys } & \multicolumn{4}{|c|}{ Girls } \\
\hline & No. & Triceps & $\begin{array}{l}\text { Sub- } \\
\text { scapula }\end{array}$ & Abdomen & No. & Triceps & $\begin{array}{l}\text { Sub- } \\
\text { scapula }\end{array}$ & Abdomen \\
\hline$<$ I & 2 & $6 \cdot 7$ & $6 \cdot 8$ & 4.8 & 4 & $7 \cdot 4$ & $5 \cdot 3$ & 3.7 \\
\hline I & 6 & $8 \cdot 6$ & $6 \cdot 5$ & $5 \cdot 5$ & 10 & $7 \cdot 0$ & $5^{\circ} 0$ & 3.7 \\
\hline 2 & 7 & $7 \cdot 7$ & 5.3 & $4 \cdot 2$ & 7 & $7 \cdot 4$ & $4^{-8}$ & $3 \cdot 5$ \\
\hline 3 & 8 & 6.6 & $5 \cdot 1$ & 3.8 & 4 & $10 \cdot 0$ & $4 \cdot 7$ & $4 \cdot 7$ \\
\hline 4 & 3 & $6 \cdot 1$ & 3.6 & $3 \cdot 2$ & 10 & 8.0 & $4 \cdot 5$ & $4 \cdot I$ \\
\hline$>5$ & 9 & $7 \cdot 3$ & 4.4 & $3 \cdot 8$ & 4 & $7 \cdot 4$ & $4 \cdot 6$ & $3 \cdot 6$ \\
\hline
\end{tabular}

Follicular hyperkeratosis was observed in eleven of the seventy-five children, but the significance of this sign as found in Central America is uncertain since it does not respond to prolonged administration of either fat or vitamin $\mathrm{A}$ in high doses (Instituto de Nutrición de Centro América y Panamá, unpublished). Similarly, the thickening of the conjunctiva seen in twenty-nine children was not associated with the dryness commonly found in vitamin A deficiency, and no Bitot's spot was found in any of the children examined. The thickening, increased vascularization and pigmentation of the exposed areas of the bulbar conjunctiva so commonly encountered in people living in rural Central America are believed to be due to a combination of trauma from sunlight, dust, and smoke from cooking fires within the houses, although nutritional deficiency may be a conditioning or sensitizing factor. Another probable influence is the high prevalence of acute conjunctivitis among the poorer children in this area.

Goitre was observed in ten children. No bone deformities suggestive of either rickets or scurvy were noted and no cases of scorbutic gingivitis were seen. Dental caries was one of the most prevalent signs, since twenty-eight of the seventy-five children had an appreciable degree of dental caries in their primary dentition. Thirty- 
one children had a transverse line of eroded enamel across the base of the incisors, suggestive of a nutritional deficiency before tooth eruption.

Although it is difficult to appraise general appearance and nutritional status in an objective and consistent manner, it is significant that the majority of children were classified as being in good or fair nutritional status. This situation was undoubtedly due to the fact that heights and weights were similarly low, so that without chronological age being taken into consideration, the appearance of the children was reasonably satisfactory. Five children, however, were considered to be in an obviously poor nutritional state.

Table 3. Prevalence of clinical signs in seventy-five pre-school children in Amatitlán, 1955-6

\begin{tabular}{|c|c|c|c|}
\hline \multirow{2}{*}{ Sign } & \multicolumn{3}{|c|}{ No. of children } \\
\hline & Positive & Negative & $\begin{array}{c}\text { Not } \\
\text { investi- } \\
\text { gated }\end{array}$ \\
\hline $\begin{array}{l}\text { Hair } \\
\text { Changes }\end{array}$ & II & 64 & 0 \\
\hline \multicolumn{4}{|l|}{ Eye } \\
\hline Thickened conjunctiva & 29 & 45 & $\mathbf{I}$ \\
\hline Conjunctival injection & 27 & $4^{1}$ & 7 \\
\hline Circumcorneal injection & I & 73 & $\mathbf{I}$ \\
\hline \multicolumn{4}{|l|}{ Skin (face) } \\
\hline Dissebacea & 2 & 73 & $\circ$ \\
\hline \multicolumn{4}{|l|}{ Lips } \\
\hline Cheilosis & 8 & 67 & ० \\
\hline Angular stomatitis & 4 & 71 & $\circ$ \\
\hline \multicolumn{4}{|l|}{ Gums } \\
\hline Marginal gingivitis & 2 & 73 & ○ \\
\hline \multicolumn{4}{|l|}{ Tongue } \\
\hline Redness & I & 73 & $\mathbf{I}$ \\
\hline Papillary hypertrophy & 5 & 69 & $\mathbf{I}$ \\
\hline Papillary atrophy & 16 & 58 & $\mathbf{I}$ \\
\hline \multicolumn{4}{|l|}{ Teeth } \\
\hline Caries & 28 & 47 & $\circ$ \\
\hline Wasted borders & 28 & 47 & $\circ$ \\
\hline Eroded enamel & $3 r$ & 44 & $\circ$ \\
\hline \multicolumn{4}{|l|}{ Mucosae } \\
\hline Paleness & 4 & 71 & o \\
\hline \multicolumn{4}{|l|}{ Glands } \\
\hline Goitre & 10 & 65 & 0 \\
\hline \multicolumn{4}{|l|}{ Skin (general) } \\
\hline Xerosis & 3 & 72 & $\circ$ \\
\hline Follicular hyperkeratosis & II & 64 & $\circ$ \\
\hline Pellagroid dermatitis & $\mathbf{I}$ & 74 & $\circ$ \\
\hline \multicolumn{4}{|l|}{ Skeleton } \\
\hline Rachitic changes & $\mathbf{I}$ & 74 & $\circ$ \\
\hline \multicolumn{4}{|l|}{ Nervous system } \\
\hline Altered reflexes & I & 74 & o \\
\hline
\end{tabular}

No external angular lesions of the eyelids, dryness of the bulbar conjunctiva, hypertrophy of the parotids or oedema were observed. 
Haemoglobin levels were determined for a total of seventy-four children. Of these, five fell below normal limits for their age as given by Wintrobe (195I); four of these were below 2 years of age. Twenty-nine of the thirty-six children for whom mean corpuscular volume was measured had values above the average given by Wintrobe, and five below. The children with the two lowest red blood cell counts had the highest mean corpuscular volumes, I07 for one and 123 for the other. Despite the tendency to macrocytosis, the red cells of the majority of the children were unsaturated; twenty-eight had mean corpuscular haemoglobin concentrations below the average given by Wintrobe and only seven above. This haematological picture is similar to that described in uncomplicated kwashiorkor, which has been shown to respond readily to therapy based exclusively on milk.

The generally high white blood cell counts were presumably associated with the high prevalence of upper respiratory and other infections.

Table 4. Prevalence of intestinal parasites in sixty pre-school children in Amatitlán, 1955-6

$\begin{array}{lc}\text { Parasite } & \begin{array}{c}\text { No. of } \\ \text { children }\end{array} \\ \text { Ascaris lumbricoides } & 30 \\ \text { Trichuris trichiura } & 7 \\ \text { Hymenolepis nana } & 3 \\ \text { Giardia lamblia } & 7 \\ \text { Trichomonas hominis } & 6 \\ \text { One type of parasite found } & \mathbf{2 7} \\ \text { More than one type of parasite } & \mathbf{1 2}\end{array}$

The prevalence of intestinal parasites is shown in Table 4. Despite the fact that only a single sample was examined, that owing to practical difficulties several hours often elapsed before the samples were brought to the laboratory, and that no concentration or staining techniques were used, thirty-nine of sixty children studied were found to have at least one type of parasite and twelve had two or more. Ascaris lumbricoides was the most common, followed by Trichuris trichiura, Giardia lamblia and Trichomonas hominis. It is of interest that not a single case of hook-worm was found.

\section{Biochemical findings}

Table 5 shows the distribution of the results obtained for each one of the nutrients studied.

Total serum protein. Of the seventy-seven studied, five children had values below $6.00 \mathrm{~g} / 100 \mathrm{ml}$ serum. Of these, three were between 2 and 4 years of age, one between I and 2, and one between 5 and 6 . In children with kwashiorkor, levels in the neighbourhood of $3-4 \mathrm{~g}$ protein/100 $\mathrm{ml}$ serum were most frequently encountered. The results for serum protein are shown in Fig. 2, arranged by age.

The lowest mean value was for the group 2 to $<3$ years of age which is also the age at which the peak of prevalence of kwashiorkor occurs in the Central American area. The differences between the levels in the different age groups were not statistically significant; nevertheless, when interpreted in the light of socio-economic, dietary and 
Table 5. Biochemical findings in the serum of pre-school children in Amatitlan, 1955-6

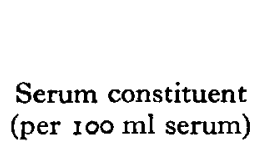

Total proteins $(\mathrm{g})$

Cholinesterase ( $\mathrm{pH}$ units)*

Alkaline phosphatase ( $p$-nitro-

phenol units)*

Amylase (Smith-Roe units)*

Vitamin A $(\mu \mathrm{g})$

Carotene $(\mu \mathrm{g})$

Riboflavin:

Free + FMN ( $\mu \mathrm{g})$

FAD $(\mu \mathrm{g})$

Ascorbic acid (mg)

\begin{tabular}{|c|c|c|c|c|}
\hline \multirow[b]{2}{*}{$\begin{array}{l}\text { No. of } \\
\text { children }\end{array}$} & \multicolumn{3}{|c|}{ Quartiles } & \multirow[b]{2}{*}{ Range } \\
\hline & First & $\begin{array}{l}\text { Second } \\
\text { (median) }\end{array}$ & Third & \\
\hline $\begin{array}{l}77 \\
37\end{array}$ & $\begin{array}{l}6.48 \\
0.87\end{array}$ & $\begin{array}{l}6 \cdot 78 \\
I .06\end{array}$ & $\begin{array}{l}7 \cdot 07 \\
1 \cdot 18\end{array}$ & $\begin{array}{r}5.80-7 \cdot 80 \\
0.53-1.68\end{array}$ \\
\hline 37 & $3 \cdot 2$ & $3 \cdot 6$ & $4 \cdot 2$ & $2 \cdot 0-5 \cdot 5$ \\
\hline 37 & 53 & 72 & 87 & $22-136$ \\
\hline 77 & I I & 17 & 22 & $0-40$ \\
\hline 77 & 23 & 42 & 60 & $6-135$ \\
\hline 37 & 0.35 & 0.55 & 0.87 & $0.14^{-2} \cdot 03$ \\
\hline 37 & $I \cdot 73$ & 2.07 & $2 \cdot 27$ & $0.85-3.00$ \\
\hline 76 & $I \cdot 04$ & $I \cdot 38$ & $1 \cdot 54$ & $0.22-3 \cdot 26$ \\
\hline
\end{tabular}

* See p. 218.
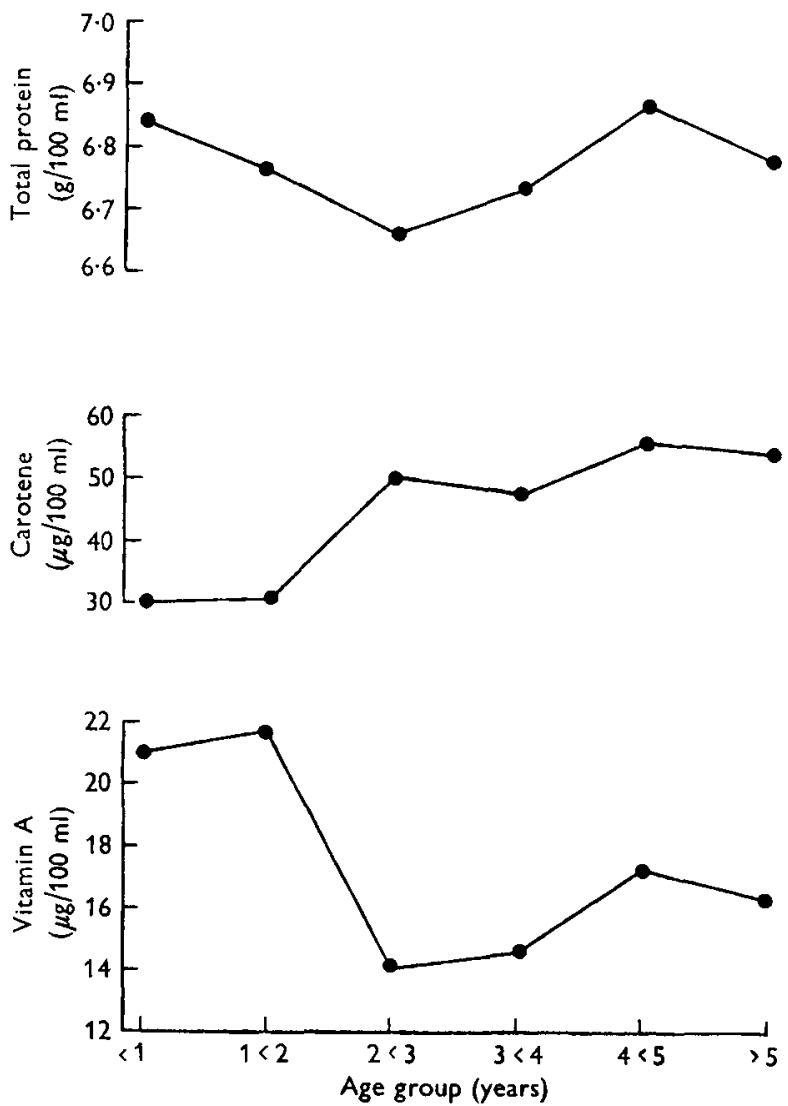

Fig. 2. Values for serum content of protein, carotene and vitamin A in pre-school children in Amatitlán. 
clinical studies of infant and child malnutrition in Central America, they constitute suggestive biochemical evidence of very poor protein nutrition during the early post-weaning period.

Serum cholinesterase. Serum-cholinesterase levels of well-nourished pre-school children have been shown not to differ significantly from those of pre-school children belonging to lower socio-economic groups in Central America, whose protein intakes are generally inadequate (Arroyave, Feldman \& Scrimshaw, 1958). On the other hand, a reduction to about a quarter of the normal level has been described in the severe protein deficiency of kwashiorkor (Scrimshaw, Béhar, Arroyave, Viteri \& Tejada, 1956).

The activity of this enzyme was determined in the serums of thirty-seven children in the $195^{6}$ survey, and the levels were found within the normal range, except for three children with values of $0.53,0.58$ and $0.59 \mathrm{pH}$ units. There was no evidence of a correlation between serum total proteins and cholinesterase. In kwashiorkor, on the other hand, low levels of serum cholinesterase are invariably associated with notably reduced total serum proteins (Scrimshaw et al. 1956).

Serum alkaline phosphatase. Bessey \& Lowry (1947) consider values above $8 p$ nitrophenol units (mM of $p$-nitrophenol/l. serum/h) as suggestive of rickets. It should be noted that no such high values were found in the group, the maximum value being 5.5 units. This result is not surprising since sunlight is abundant in the area inhabited by the population under study and consequently rickets is not a nutritional problem. However, alkaline phosphatase was determined in our investigation because low enzyme levels have been found in children with kwashiorkor (Dean \& Schwartz, 1953; Scrimshaw et al. 1956), which return to normal after recovery from the disease. For this reason we were interested in low values rather than high ones.

Sunderman (1942) gives as normal limits in children $5^{-12}$ Bodansky units, equivalent to $2 \cdot 8-6.7 p$-nitrophenol units. Four children in this study showed values lower than $2 \cdot 8 p$-nitrophenol units $(2 \cdot 00-2 \cdot 59)$, and the rest of the values fell within normal limits. It will be noted, however, that a highly significant positive correlation $(r=0.519,36$ d.f.) was found between total serum protein and alkaline phosphatase.

Serum amylase. The values for thirty-seven children in the 1955 survey ranged from 22 to 136 Smith \& Roe (1949) units, equivalent to $24-150$ Somogyi units. Somogyi (1940, 194I) found the limits for a large number of ambulatory subjects to be 60-180 with $80 \%$ between 80 and 150 Somogyi units.

In eighteen children with kwashiorkor previously studied by us the average value was 45 Somogyi units (range 10-124) on admission to the hospital and Io6 (range $5 \mathrm{I}-15 \mathrm{I})$ after treatment.

In the present study relatively many of the pre-school children had low serumamylase activity, but the evaluation of the total group gave no evidence of any correlation with total serum proteins.

Serum vitamin $A$ and carotene. The results of the determination of serum vitamin A and carotene in seventy-seven children from both the 1955 and 1956 surveys are given in Table 5. It is interesting to compare these values with those obtained for private nursery-school children in Guatemala City who belong to the upper socio-economic 
group in an urban community and were considered adequately nourished. The mean value for this group of twenty-one children was $42.7 \mu \mathrm{g}$ vitamin A/100 ml serum (s.D. $=9.9)$; none of the children in the rural group had serum vitamin A levels as high.

Previous studies in the area suggest that nutritional stress might differ greatly among the different age groups included (Scrimshaw, Béhar, Viteri, Arroyave \& Tejada, I957). The results arranged by year age groups are presented in Fig. 2 and reveal maximum occurrence of extremely low values in the children between 2 and 4 years of age, even though some extremely low values were also found in the other age groups.

Data are scarce for nutrient levels in the serum of children of the age range covered in our study. Szymanski \& Longwell (I95 I), however, present values for serum levels of vitamin A and carotene in children of similar ages in Denver, Colorado, U.S.A., from the upper middle-class economic group. The medians for the ages from I year and 9 months to 6 years ranged from 44 to $3^{6} \mu \mathrm{g} / \mathrm{I} 00 \mathrm{ml}$, values which are in agreement with those for the upper-income urban group in Guatemala.

Bessey (1954), in his critical evaluation of the interpretation of serum vitamin values, has stated that plasma-vitamin A levels below $15^{-20} \mu \mathrm{g} / 100 \mathrm{ml}$ are presumptive evidence of a deficiency that may be clinically recognizable. By this standard, at least $44 \%$ of the children in the group studied (below $15 \mu \mathrm{g} / \mathrm{roo} \mathrm{ml}$ ) were in a state of vitamin A deficiency.

Fig. 2 shows the mean values for serum carotene at each year of age. The rise with age may be a reflection of the progressive increase in intake of food supplying carotene as children advance into school age.

Serum riboflavin. The serum levels of riboflavin, both as free plus flavin mononucleotide (FMN) and as flavinadenine dinucleotide (FAD), are summarized in Table 5. Direct data on serum-riboflavin levels in adult man in relation to intake were contributed by Bessey, Horwitt \& Love (1956). In their study, seven of the ten subjects maintained on a riboflavin-deficient diet had free plus FMN riboflavin of $0.04-$ $0.34 \mu \mathrm{g} / 100 \mathrm{ml}$ serum. Burch et al. (1948) found in thirteen well-nourished adults a range between 0.3 and $1 \cdot 3 \mu \mathrm{g} / 100 \mathrm{ml}$, and Snyderman, Ketron, Burch, Lowry, Bessey, Guy \& Holt (1949) take $0 \cdot 5^{-1} \cdot 5 \mu \mathrm{g} / \mathrm{roo} \mathrm{ml}$ as the adequate blood levels of free plus FMN riboflavin for infants. On this basis our results show that at least onequarter of the children studied had values suggestive of deficiency. Bessey et al. (1956) conclude that the use of values for free plus FMN riboflavin content of plasma as an index of riboflavin nutritional status is complicated by several factors, mainly the occurrence of individuals who show very high values regardless of their nutritional adequacy in riboflavin. Therefore, the children showing high values in our study did not necessarily have an adequate intake of this vitamin.

Serum levels of FAD are even more difficult to interpret. Suvarnakich, Mann \& Stare (1952) favour FAD levels as indices of nutritional adequacy of riboflavin in view of their greater stability among well-nourished individuals. A decrease in FAD levels on riboflavin-deficient diets has been described in monkeys (Mann, Watson, McNally \& Goddard, 1952) and rats (Burch et al. 1948). In the study of Bessey et al. (1956) on 
human adults, however, the plasma level of FAD was not decreased significantly in spite of a degree of dietary riboflavin restriction sufficient to produce clinical evidence of deficiency.

In our investigation, ten of the thirty-seven children studied had FAD riboflavin levels below the lower limit of $\mathrm{I} \cdot 8 \mu \mathrm{g} / \mathrm{I} 00 \mathrm{ml}$ found by Burch et al. (1948) for wellnourished adults. There was no demonstrable correlation of these values with free plus FMN riboflavin content of serum.

Ascorbic acid. Inspection of the values for serum ascorbic acid obtained from the study of seventy-six children showed no biochemical evidence of ascorbic-acid deficiency in this sample of pre-school children. The presence of four values below $0.4 \mathrm{mg} / \mathrm{roO} \mathrm{ml}$ is of course not unexpected as part of the distribution curve and has no bearing on the general conclusion from the biochemical study of the blood serum that ascorbic-acid deficiency can definitely be excluded.

\section{DISCUSSION}

The degree of retardation in height and weight alone, as judged by the standards employed, suggests that nearly all of the children in the sample were grossly malnourished. Other INCAP studies of growth and maturation have provided no evidence that genetic factors play a major part in growth retardation as observed in Central America, but instead indicate a relation between the growth retardation and an inadequate diet (Scrimshaw et al. 1955). Furthermore, the dietary evidence that, in general, the calorie and protein intakes of these children were markedly insufficient for their age is enough to account for the degree of growth retardation encountered.

It will be noted that the intakes of vitamin $A$ and riboflavin would themselves be expected to be limiting even if the intakes of protein and calories were adequate. Furthermore, the biochemical evidence of vitamin A and riboflavin deficiency is compatible with the low dietary intake of these vitamins. Presumably owing to the fact that both of these vitamins come from common food sources, highly significant positive correlations were found between serum vitamin $\mathrm{A}$ and both total riboflavin $(r=0.43 x, 34$ d.f. $)$ and free plus FMN riboflavin $(r=0.504,34$ d.f. $)$. The failure to observe more frequent and pronounced clinical signs attributable to the deficiency of these two vitamins may well have been due to decreased requirement because of the growth failure and decreased body mass due to protein and calorie deficiency.

Further evidence of protein deficiency was the frequency of hair changes of the type found in kwashiorkor. The hair changes in kwashiorkor respond rapidly to the administration of skim milk. Serum-protein levels have been shown to be relatively insensitive indicators of protein malnutrition until the deficiency becomes so severe as to be clinically evident. Although the protein deficiency was not sufficient to produce clinical oedema in any of these children, several had definitely low values of either serum protein, cholinesterase or amylase. The lowest serum-protein values, lowest dietary protein intakes and greatest number of hair changes were all observed in the children from 2 to 3 years of age, even though there was no consistent individual association among the three types of observation. It should be re-emphasized that 
the protein intakes as given are misleading because of the poor quality of the protein. The biological value of the protein in the diet is not known with sufficient accuracy to permit correction of the figures, but it is probable that the value is only about half that of animal protein.

The relatively small amount of subcutaneous fat encountered on physical examination and reflected in the reduced thickness of the subcutaneous skinfolds is readily understandable in view of the low calorie intakes recorded.

Determinations of the serum vitamin A and carotene are of particular value in interpreting situations in which an appreciable part of the vitamin A activity comes from dietary carotene. A significant correlation between these two serum values was found for the group of children who were 2 years of age or older $\left(r=0.6 \mathrm{r}_{4}, 54\right.$ d.f.) but not for the younger children (less than 2 years) $(r=0.245,20$ d.f.). From the dietary findings, on the other hand, it can be estimated that, for both age groups, about the same proportion of vitamin $\mathrm{A}$ activity came from pre-formed vitamin $\mathrm{A}$ as from carotene. This inconsistency might be due to a lesser degree of absorption of carotene in the younger group with the type of diet eaten. Other studies have revealed poor utilization of carotene with diets low in animal protein and fat similar to those encountered in this study (Roels, Trout \& Dujacquier, 1958). Thus, the actual dietary supply of vitamin A may be physiologically lower than the findings imply because of reduced absorption and conversion of the carotene, which accounts for the major part of the calculated vitamin A activity.

The generally high ascorbic-acid levels in serum do not reflect the relatively large number of children surveyed who were reported to have very insufficient intakes of this vitamin. This disagreement has been previously observed in nutritional studies in the area and has been tentatively attributed to incomplete dietary information about the sources of ascorbic acid, as these are usually consumed by the children as betweenmeal snacks. On the other hand, the absence of any clinical signs suggestive of ascorbic-acid deficiency is compatible with the biochemical findings.

SUMMARY

I. The clinical, biochemical and dietary findings in a survey of seventy-seven children under 7 years of age living in a small semi-rural community in the Guatemalan highlands are described.

2. Eighteen of thirty-two children received less than $5 \mathrm{~g}$ protein of animal origin daily, and intakes of vitamin A, riboflavin, ascorbic acid and fat were also very low.

3. Compared with well-nourished children, nearly all of those studied fell below the sixteenth percentile in weight and more than one standard deviation below the mean in height, even though the height:weight ratio was frequently normal.

4. In general, measurements of skinfold thickness over the triceps, abdomen and subscapular area were all very low.

5. Of the clinical signs possibly related to nutritional status, alterations in the texture, pigmentation and implantation of the hair were common, as was follicular hyperkeratosis and goitre. The almost universal thickening and increased vasculariza- 
tion of the bulbar conjunctiva were believed to be related to exposure to dust, smoke and recurrent conjunctivitis; vascular invasion of the corneal border was doubtfully observed in one case and nasolabial seborrhoea in two of seventy-five children. No changes suggestive of either rickets or scurvy were noted.

6. Twenty-eight of seventy-five children had a significant degree of dental caries in their primary dentition and thirty-one had a transverse line of eroded enamel across the base of the incisors.

7. Only five children had haemoglobin levels abnormally low for their age group.

8. Infestation with Ascaris lumbricoides was exceedingly common, followed in order of prevalence by that with Trichuris trichiura, Giardia lamblia and Trichomonas hominis. (Hookworm did not occur in this population.)

9. Five children had serum-protein levels below $6 \mathrm{~g} / 100 \mathrm{ml}$ and about the same proportion had abnormally low levels of serum cholinesterase and alkaline phosphatase. Serum protein and alkaline phosphatase were positively correlated.

I0. Half of the seventy-seven children had serum-vitamin A levels below $20 \mu \mathrm{g} / 100 \mathrm{ml}$ and serum-carotene levels were also low, particularly in the younger children studied.

II. Serum levels of free plus flavin mononucleotide riboflavin averaged $0.66 \mu \mathrm{g} /$ $100 \mathrm{ml}$ and flavinadenine dinucleotide riboflavin $2.07 \mu \mathrm{g}$; the distribution of these values suggested a relative deficiency of riboflavin.

12. Ascorbic-acid values averaged $\mathrm{I} \cdot 32 \mathrm{mg} / \mathrm{1} 00 \mathrm{ml}$ serum and there was neither biochemical nor clinical evidence of ascorbic-acid deficiency in any of the children.

13. It is concluded that nearly all of the children were sufficiently malnourished to be markedly retarded in growth and development and that a small proportion were on the borderline of severe protein deficiency of the kwashiorkor type.

14. The three types of findings, clinical, biochemical and dietary, served to complement one another and made possible an evaluation of the nutritional status which could not have been achieved without all three.

This investigation was supported in part by research grant no. A-981 from the National Institute of Arthritis and Metabolic Diseases, Public Health Service, and by the Nutrition Foundation.

All of the 1955 examinations were done by M. B. In 1956, Drs J. Rui Morgado, Antonio Pereira Nunes and Lorna G. MacDougall, WHO fellows from Mozambique, Angola and Kenya respectively, and Hugo Carrascosa from Guatemala, examined some of the children under the direct supervision of M. B.

\section{REFERENCES}

Arroyave, G., Feldman, R. \& Scrimshaw, N. S. (1958). Amer. 7. clin. Nutr. 6, 164. Béhar, M., Ascoli, W. \& Scrimshaw, N. S. (1958). Bull. World Hlth Org. 19, 1093.

Bessey, O. A. (1954). In Methods for Evaluation of Nutritional Adequacy and Status, pp. 59-68. Chicago: U.S. Quartermaster Food and Container Institute for the Armed Forces.

Bessey, O. A., Horwitt, M. K. \& Love, R. H. (1956). F. Nutr. 58, 367 .

Bessey, O. A. \& Lowry, O. H. (1947). In Meals for Millions, pp. 167-92. Report of the New York State Joint Legislative Committee on Nutrition.

Bessey, O. A., Lowry, O. H. \& Brock, M. J. (1946). F. biol. Chem. r64, 32 I. 
Bessey, O. A., Lowry, O. H., Brock, M. J. \& Lbpez, J. A. (1946). F. biol. Chem. 166, 177.

Brožek, J. \& Keys, A. (1951). Brit. F. Nutr. 5, 194.

Burch, H. B., Bessey, O. A. \& Lowry, O. H. (r948). F. biol. Chem. 175, 457.

Carrascosa, H. R. (1956). Estudio clínico-nutricional en niños de edad pre-escolar de un barrio pobre de la Ciudad de Guatemala. Thesis, University of San Carlos, Guatemala.

Dean, R. F. A. \& Schwartz, R. (1953). Brit. F. Nutr. 7, 13 I.

Flores, M. \& Garcia, B. (1960). Brit. F. Nutr. 14, 207.

Instituto de Nutrición de Centro América y Panamá (1952). Curvas de Crecimiento de Niños. (Para uso en Centro América y Panamá.) Octubre.

Instituto de Nutrición de Centro América y Panamá (1955). Bol. ofic. Sanit. pan-amer. Suppl. no. 2, p. 225 .

Lowry, O. H. \& Hunter, T. H. (1945). F. biol. Chem. 159, 465.

Lowry, O. H., Lopez, J. A. \& Bessey, O. A. (1945). F. biol. Chem. 16o, 6og.

Mann, G. V., Watson, P. L., McNally, A. \& Goddard, J. (1952). F. Nutr. 47, 225.

Muños, J. A. \& Pérez-Avendaño, C. (1954). Rev. Col. Méd. Guatemala, 5, 117.

Pett, L. B. \& Ogilvie, G. F. (1957). Canad. Bull. Nutr. 5, x.

Reinhold, J. C., Tourigny, L. G. \& Yonan, V. W. (1953). Amer. F. clin. Path. 23, 645.

Roels, O. A., Trout, M. \& Dujacquier, R. (1958). F. Nutr. 65, 115.

Scrimshaw, N. S., Béhar, M., Arroyave, G., Viteri, F. \& Tejada, C. (1956). Fed. Proc. $15,977$.

Scrimshaw, N. S., Béhar, M., Pérez, C. \& Viteri, F. (1955). Pediatrics, Springfield, 16, 378.

Scrimshaw, N. S., Béhar, M., Viteri, F., Arroyave, G. \& Tejada, C. (1957). Amer. F. Publ. Hlth, 47, 53.

Smith. B. W. \& Roe, J. H. (1949). F. biol. Chem. 179, 53.

Snyderman, S. E., Ketron, K. C., Burch, H. B., Lowry, O. H., Bessey, O. A., Guy, L. P. \& Holt, L. E. Jr. (1949). F. Nutr. 39, 219.

Somogyi, M. (1940). F. biol. Chem. r34, 315 .

Somogyi, M. (1941). Arch. intern. Med. 67, 665.

Sunderman, F. W. (1942). Amer. F. clin. Path. 12, 404.

Suvarnakich, K., Mann, G. V. \& Stare, F. J. (1952). F. Nutr. 47, 105.

Szymanski, B. B. \& Longwell, B. B. (195I). F. Nutr. 45, 43 I.

Wintrobe, M. M. (195I). Clinical Hematology, $3^{\text {rd }}$ ed. Philadelphia, Pa.: Lea and Febiger. 